\title{
Ancient buoyancy devices in Sweden: floats made of reed, club-rush, inflated skins and animal bladders
}

\section{Isak Lidström \& Ingvar Svanberg}

To cite this article: Isak Lidström \& Ingvar Svanberg (2019) Ancient buoyancy devices in Sweden: floats made of reed, club-rush, inflated skins and animal bladders, Folk Life, 57:2, 85-94, DOI: 10.1080/04308778.2019.1646390

To link to this article: https://doi.org/10.1080/04308778.2019.1646390

曲 Published online: 30 Jul 2019.

Submit your article to this journal $๘$

LII Article views: 40

Q View related articles ¿

View Crossmark data 


\title{
Ancient buoyancy devices in Sweden: floats made of reed, club-rush, inflated skins and animal bladders
}

\author{
Isak Lidström ${ }^{a}$ and Ingvar Svanberg ${ }^{b}$ \\ aDepartment of Sport Science, Malmö University, Malmö; 'blnstitute for Russian and Eurasian Studies, \\ Uppsala University, Uppsala
}

\begin{abstract}
This article sets out to discuss the material culture of traditional physical education from an ethnobiological point of view. The focus is on the use of reed, Phragmites australis Trin. ex Steud., club-rush, Schoenoplectus lacustris L., inflated skins and animal bladders when making buoyancy devices used by children and adolescents for learning to swim. As these teaching methods occurred from thousands of years ago up to very recently, it is argued that child-related practices connected with the bio-cultural domain and arising out of human-biota interaction have noticeably transcended time and societal changes.
\end{abstract}

\section{KEYWORDS}

Child culture; ethnobiology; sport history; physical education; swimming equipment; traditional games

\section{Introduction}

Water has always been an element that human beings have striven to master, either by floating on it or by swimming through it. Regarding the latter, several incentives may present themselves that spur a desire to learn the art of swimming. Whereas some might consider it as a form of life insurance, others swim just for fun or perhaps even for competitive reasons. Swimming has thereby, throughout history, come to exist within different fields, such as play, sport and physical education.

Among ethnologists, sociologists and sports historians, it is common to make a distinction between the traditional games of pre-modern agrarian societies, and those of modern sports of industrialized society. Although this necessarily oversimplifies a complex history somewhat, the latter have been defined as competitive institutionalized physical activities, characterized by elements such as rationalization, standardization and a constant quest for development in which performances are to be improved and records broken. The former, on the other hand, emphasizes recreation, festivity, and communal sociality and interaction. Moreover, traditional games, or folk games, vary from place to place in their equipment and rules. Additionally, the outcome of the competition is frequently secondary to the joy and amusement arising from participation. ${ }^{1}$

When it comes to physical education, there is no clear distinction between past and present learning practices, as is the case with traditional games and modern sports. It is 
nonetheless indisputable that, throughout history, there have always been methods for teaching children sports and physical skills. ${ }^{2}$ The concept of 'physical education' is often associated with formal learning practices in schools, at universities and other institutions. ${ }^{3}$ However, in this brief article, one that deliberately chooses an ethnological point of view, the intention is to go beyond the practices that are stipulated in curricula. We will rather discuss traditional methods of physical education, i.e. informal practices that are based on old knowledge and customs with roots in pre-modern society. A special focus here is directed towards the use of implements made from local biological resources within these practices. Hence, it is particularly relevant to discuss how the material culture of traditional physical education can be understood as the outcome of a biocultural domain that arises in the relationship between human beings and their surrounding biota. ${ }^{4}$

However, it should be noted that the concept of 'traditional' is a vague term to use within human science research. In the study of human life and especially in activity contexts within the surrounding biota, ${ }^{5}$ many researchers now prefer to speak of 'local knowledge' rather than 'traditional knowledge'. ${ }^{6}$ Many so-called 'folk traditions' may turn out to be neither very old nor traditional at all. To give just one example, it is well known that contemporary Swedish Christmas customs (including the Christmas tree, Jultomten i.e. the Swedish version of Santa Claus, typical food for Christmas Eve, etc.) are largely the result of international, commercial influences promoted during the late nineteenth and twentieth centuries. ${ }^{7}$ Consequently, one has to be careful when talking about traditions or traditional knowledge. ${ }^{8}$ Nevertheless, while bearing this caveat in mind, we do sometimes encounter customs and habits that have their roots back in antiquity. One instance worth mentioning is the capture of wall lizards (Podarcis muralis, P. sicula) by Italian children with the help of a grass snare. This is an ancient technique, reproduced, for example, on the statue known as Apollo Sauroctonus, from the fourth century B.C., created by the Greek sculptor Praxiteles (Figure 1). ${ }^{9}$ Another example is the custom addressed in this article, namely the making of floats used by those learning to swim. Such floats have been made of various materials, whereof the common club-rush, Schoenoplectus lacustris, Eurasian reed Phragmites australis ${ }^{10}$, and pig's bladders ${ }^{11}$ provide a few examples.

The common club-rush and Eurasian reed are common helophytes that grow in lakes and rivers in most parts of Sweden, although they are rarer in the north. ${ }^{12}$ Both species have been widely used for animal fodder, various kinds of handicrafts, and for thatching roofs respectively, in their various areas of distribution. ${ }^{13}$

The data found in Swedish folklore archives and in scattered notes in older literature constitute invaluable sources when it comes to mapping and understanding the diversity of pre-industrial peasants' relationship to the biota and their ecology in the eighteenth and nineteenth centuries. ${ }^{14}$ We have assembled data from various published and unpublished sources about floatation devices made of animal bladders and bundles of reed and rush. 


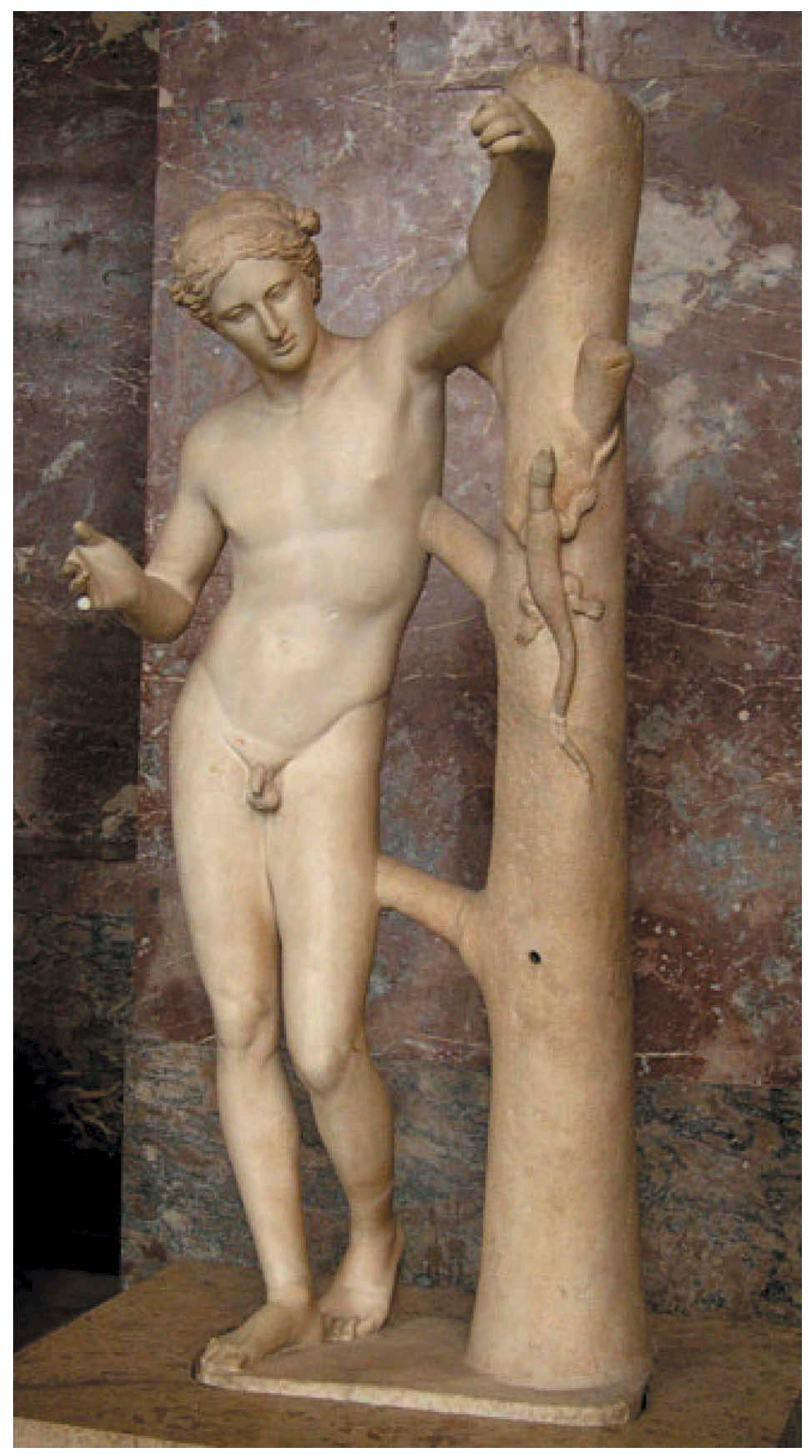

Figure 1. Roman copy of Apollo Sauroctonus from the 1st-2nd centuries AD after a Greek original from the 4th century BC (Louvre Museum, Paris).

\section{Swimming equipment}

In the classic handbook for swimming De arte natandi, written by academic theologian Everard Digby (c.1550-c.1605), we read, 'Lesson 2 is learning to swim. This should preferably be done with someone supporting you under the chin, or by using water wings made of two inflated pigs' bladders. ${ }^{15}$

The use of inflated animal skins and bladders as floats is a very ancient method in the history of swimming, especially within military contexts. The oldest example can be seen on a bas-relief from Nimrud, Mesopotamia (now in the British Museum). It shows ancient Assyrians using skins, presumably of goats, as swimming floats 3000 years ago 
(Figure 2). Such bladders and inflated skins are known to have been used as swimming equipment in many parts of the world. ${ }^{16}$ James Hornell discusses the origin and distribution of such equipment, concluding that inflated skin-float has a historical record of greater antiquity.' An interesting example mentioned by Hornell is Shakespeare's play Henry VIII, co-written with John Fletcher, and also known by the alternative title All is True, where Cardinal Wolsey laments that he had 'ventured like little wanton boys that swim on bladders,' far beyond his depth. ${ }^{17}$ From all over nineteenth century Sweden, swine bladders are known to have been used for the same purpose. ${ }^{18}$

In Olaus Magni Historia de Gentibus Septentrionalibus ('Description of the Northern Peoples') from 1555, we find an illustration (Figure 3) showing a young man learning to swim with the help of an inflated sack of leather (Book 10, Ch. XXVII). ${ }^{19}$ Such leather sacks used as buoyancy devices are also known from Sweden during later centuries. ${ }^{20}$ Sámi in Sweden also used the inflated stomach of a reindeer as a means of floating when learning to swim. ${ }^{21}$

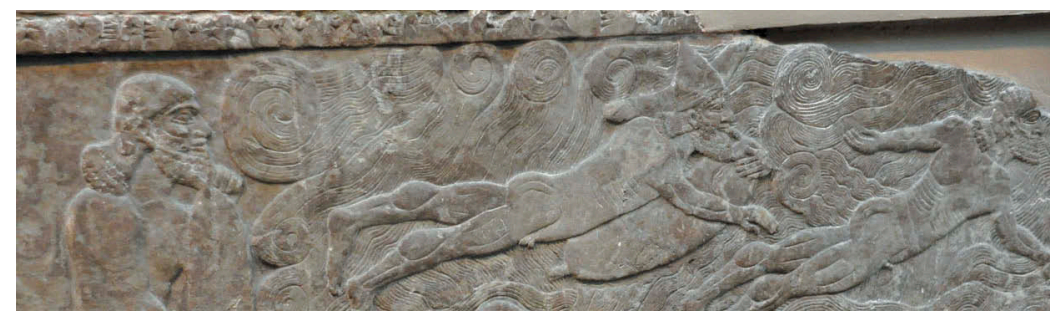

Figure 2. Assyrian soldier swimming with the help of an inflated goat skin (British Museum).

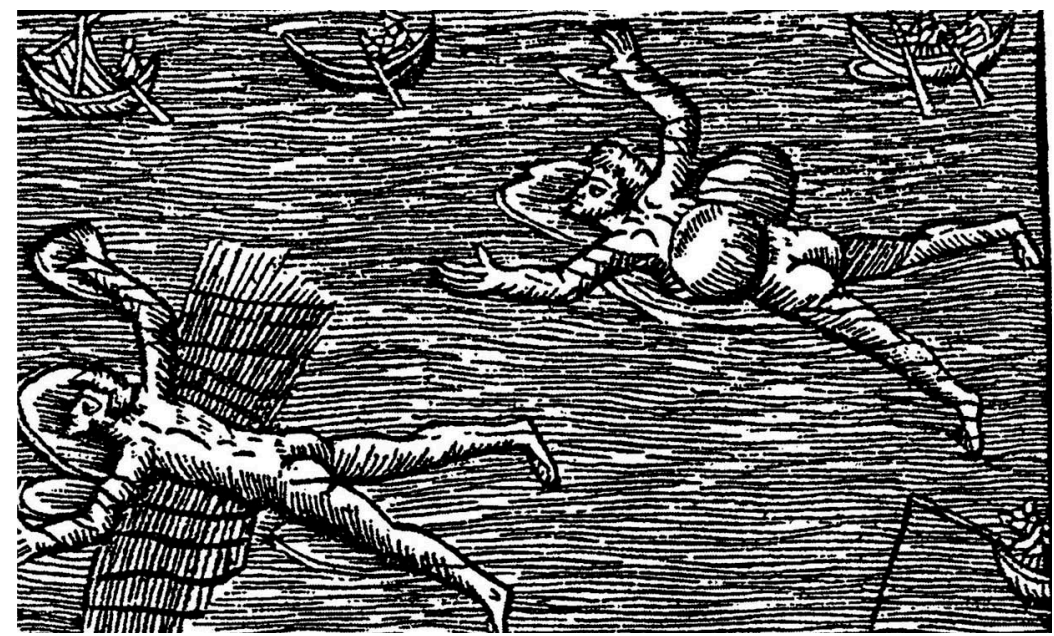

Figure 3. Floating devices in Olaus Magni Historia de Gentibus Septentrionalibus ('Description of the Northern Peoples') from 1555. 


\section{Reed bundle floats}

Another man pictured on the left-hand side of the illustration in Olaus Magnus's book is using a reed bundle float (see Figure 3). According to Olaus Magnus, the boys use a 'manipulum leuium arundinum fungosarum', i.e. a float made of bundles of light, spongy reed. ${ }^{22}$

As has been pointed out by ethnologist John Granlund, such swimming aids were already known of in Ancient Rome as scirpa ratis. ${ }^{23}$ However, the making of swimming floats or 'swim-belts' of reed or club-rush has also occurred in more recent times in Sweden. In his Flora lapponica, Carl Linnaeus mentions how boys in his home province of Småland used bundles of club-rush as buoyancy belts when they were taught to swim. $^{24}$

\section{The emergence of modern swimming education in Sweden}

Before the industrialization of Sweden in late nineteenth century, the ability to swim was a skill that only a few could master. It was up to the individual to learn how to float and how to move through water. In the late eighteenth century, however, the situation changed, and swimming education became a public topic of discussion in Sweden. ${ }^{25}$

Already by 1760 , the first official military swimming school in Sweden, intended for future officers, was established in Karlskrona. Alongside military forms of competition such as fencing and riding, swimming became also the first sport to be organized in Sweden. This started in 1796, the year when the Upsala Swimming Society (Upsala Simsällskap) was founded, most likely as the first of its kind in the world. After the foundation, similar organizations were established in several Swedish cities. $^{26}$ Noteworthy is that the establishment of swimming societies was preceded by discussions on the societal benefits of swimming skills. ${ }^{27}$ In 1787, for example, an essay contest was organized by the Royal Patriotic Society in Sweden, whose participants were supposed to write about the best method for teaching young people to swim. Among many methods advocated by one of the competitors, Arvid Faxe, one recommended that the learner should lie prostrate on the water, either with a corkboard or with inflated ox bladders under the chest. $^{28}$

Another competitor in the essay contest, August Nordenskiöld, also supported the use of buoyancy devices, which might consist of empty bottles, 'cork sweaters', bladders or two bunches of rush. However, the means of flotation that Nordensköld preferred was a sawboard (sågbräde) with rounded edges. ${ }^{29}$ All these methods, which included such devices, were nevertheless dismissed by a third participant in the competition, George Schumacher. 'Cork Sweaters, swine bladders under the chest etc. mean nothing', stated Schumacher, as these methods would make children rely on the buoyancy belt and so on rather than their own strength. ${ }^{30}$

The discussions that arose in the late eighteenth century mark a turning point in the history of swimming education in Sweden, as swimming skills began to be viewed as a concern not only for the individual but also for the whole nation. In the spirit of utilitarianism, Arvid Faxe stressed that the art of swimming was an important tool in the pursuit to provide the state with useful citizens. ${ }^{31}$ This opinion can be understood 
in light of a contemporary development in Sweden in which physical culture came to have an increasing prominent significance in creating a national identity. In the early nineteenth century, the Swedish pioneer of physical education Pehr Henrik Ling founded the subsequently world famous 'Swedish Gymnastics System' in which the physical tension of the human body reflected virtues such as morality, discipline and self-control. ${ }^{32}$

Swimming became a part in this expanding interest in physical culture. The ability to swim began, so to speak, to be closely aligned with the modern idea of citizenship. Following these discussions, swimming education became increasingly a social concern in Sweden during the nineteenth century, as it was conducted in schools and educational institutions. During the early decades of the century, swimming education was introduced into some secondary schools. From the 1860s onwards, even school children of the elementary schools of Stockholm and Gothenburg were, during the summer, given the opportunity to learn how to swim. ${ }^{33}$ Although it is clear that the modern Swedish state required subordinates who were able to move through water, the swimming knowledge remained low for a long time. In 1913 only 22.4 per cent of the Swedish school children could swim. ${ }^{34}$

\section{Evidence in folkore archives, newspaper articles and fiction}

Although Schumacher opposed instruction methods where swimming aids were included, it is nevertheless clear that bladders, reeds and rushes continued to fill an important function in the traditional swimming education that took place outside schools or educational institutions. This is evident from several accounts in the folklore archives, in which their use is described, from southernmost Sweden all the way up to the northern part of the country. An account collected in 1935 regarding Stenestad parish in the province of Skåne briefly states that 'swim belts' were earlier made of bundles of club-rush. From Alseda parish in Småland, Gottfried Wagnér recorded that the locals gathered reeds in the creek and made buoyancy belts of them. Another record from Gryteryd parish, Småland, mentions the use of reed bundles for the same purpose. ${ }^{35}$

Ethnologist Sven Lampa, who had documented local swimming methods in the province of Västergötland, mentioned that the children in Forshem parish used a bundle of club-rush, which they put under the chest when they learned to swim. ${ }^{36}$ Club-rush is also mentioned as the usual material from the parishes of V. Tunhems parish and Alingsås in the same province. In the 1870s in Husby parish, in the province of Östergötland, they also used 'swim belts' made of club-rush bundles, which were placed in the folds of their arms and connected by a string in front of the chest. The same practice is recorded from Västertälje parish. In Kimstads parish in the same province, the 'swim belts' were made of reed. Reed was also used in Fläckebo parish, Västmanland, when making floatation devices. In the late nineteenth century almost all ten-year-old boys in the parish of Tuna, Dalarna were taught to swim using 'swim belts' made of reed. ${ }^{37}$

Although buoyancy belts made of cork or a simple wooden plank were predominant in the mid-nineteenth century ${ }^{38}$, reed or club-rush bundles were still in use here and there. Swedish author Artur Lundkvist actually mentions the use of reeds for flotation 
in a novel published in 1941. A bathing place by a river is described through the eyes of a young boy as follows:

When you went there afterwards there were the remnants of water wings made of reeds and other things too that they had plaited from the same materials, perhaps with water lilies stuck into them; you got the feeling of a lingering scent (of skin, hair and soap) and could see where their bodies had lain in the grass. ${ }^{39}$

In the collections of the Nordic Museum there is also a film recording from 1946, made in N. Rörum parish, Skåne, in the southernmost part of Sweden, which describes how to make a buoyancy device of club-rush. ${ }^{40}$ One year earlier, a tragic accident had occurred in northern Sweden when a twelve-year-old boy was pulled down by the current and drowned in the River Bure in the province of Västerbotten, while he was learning to swim with the support of a bundle of club-rush. ${ }^{41}$

Even today, some people still have their own personal memories of learning to swim with the aid of this traditional method. In 2015, a local Swedish newspaper wrote in celebration of Ulla Johansson's 105th birthday. When recollecting memories from her childhood, she particularly mentioned how she had learned to swim by floating on small rafts made of reed. ${ }^{42}$

\section{Other countries}

The custom of using bundles of reed or club-rush as buoyancy devices is known from many parts of Europe. We have a few scattered notes from the ethnographic and ethnobotanical literature, which can be given as examples. There are, for instance, some records from Jutland, Denmark. ${ }^{43}$ German Renaissance botanist Hieronymus Bock writes in his herbal, New Kreütterbuch, about the rush Schoenoplectus lacustris, used when boys are learning to swim. ${ }^{44} \mathrm{We}$ also have evidence from nineteenth century Germany, for instance from Mecklenburg, where the species was known as swennbeisen (Standard German Schwimmbinsen 'swimming-rush'), as it was used for making buoyancy belts. ${ }^{45}$ Furthermore, its use for the same purpose is described from Switzerland and from the mountain lakes of Upper Austria and Carinthia. ${ }^{46}$ This use of club-rush is also reported from the Bodensee area. ${ }^{47}$ From the village of Urvaste, in the county of Võru in Estonia (Figure 4), there is an interesting description of how the children used bundles of rush or reed when they learnt to swim. ${ }^{48}$

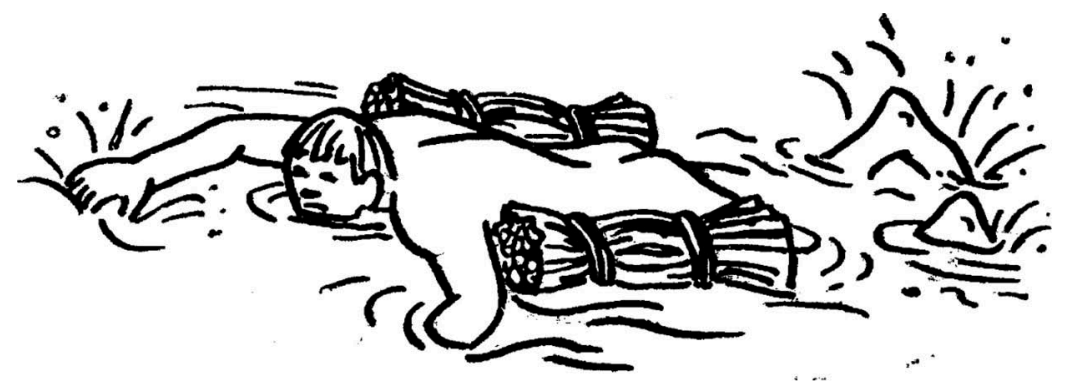

Figure 4. Floating devices on a drawing from Võru in Estonia. Source: A. Kalamees, Eesti rahvamänge (Tallinn, 1960), p. 160. 


\section{Concluding remarks}

What we have described in this article is a widespread custom considered to have been, for the most part, permanently discontinued, since bladders and bundles of reed or club-rush have nowadays been replaced by manufactured plastic floatation devices. It should nevertheless be noted that the use of reed, club-rush and animal bladders in traditional swimming education was a method that lasted for a very long time. This indicates that some practices that are related to the play, games and customs of children and adolescents have been stable phenomena over long periods of time. Within these practices, we sometimes encounter fascinating survivals of old knowledge. ${ }^{49}$ It seems especially clear that child-related practices connected with the bio-cultural domain and arising out of human-biota interaction, have noticeably transcended time and societal change.

\section{Notes}

1. E. Dunning, 'The structural-functional properties of folk-games and modern sports: A sociological analysis,' Sportwissenschaft 3 (1973), 28; A. Guttmann, From ritual to record. The nature of modern sports (New York: Columbia University Press, 1978); M. Hellspong, 'Slå trilla. En lek på gränsen mellan folklig och modern idrott,' Rig 73 (1990), 12-5; I. Lidström, 'Batting 'runders' on the island of Runö. The incorporation of English bat-andball games into a traditional Easter celebration (or how the shoal of 'Donkom' got its name),' Arv. Nordic yearbook of folklore 73 (2017), 29.

2. D. B. van Dalen, E. D. Mitchell and B. Bennett, $A$ world history of physical education (New York: Prentice-Hall, 1953).

3. Cf M. Phillips and A.P. Roper, 'History of physical education,' in The handbook of physical education, eds. D. Kirk, D. Macdonald and M. O'Sullivan (London: Sage Publication, 2006), p. 125.

4. C. Lévi-Strauss, La pensée sauvage (Paris: Plon, 1962), pp. 3-15.

5. W. Balée, Footprints of the forest: Ka'apor ethnobotany: The historical ecology of plant utilization by an Amazonian people (New York: Columbia University Press, 1944), p. 13.

6. C. Antweiler, 'Local knowledge and local knowing. An anthropological analysis of contested "cultural products" in the context of development,' Anthropos 93 (1998), pp. 469-94.

7. N-A. Bringéus, Årets festdagar (Stockholm: Carlsson, 2006), pp. 132-5; E. J. Hobsbawm, 'Introduction: inventing traditions,' in The invention of tradition, eds. E. J. Hobsbawm \& T. O. Ranger (Cambridge: Cambridge University Press, 1992), pp. 1-14.

8. M. Hugoson, 'Instant tradition: The introduction of the Swedish Easter tree,' Folklore 117 (2006), 75-86.

9. I. Svanberg, 'Plant knowledge as indicator of historical cultural contacts: Tanning in the Atlantic fringe,' in Travelling Cultures and Plants: the Ethnobiology and Ethnopharmacy of Migrations, eds. A. Pieroni and I. Vandebroek (Oxford: Berghahn Books, 2007), p. 233.

10. C.A.M. Lindman, Bilder ur Nordens flora, vol. 3 (Stockholm: Wahlström \& Widstrand, 1905), p. 329; I. Svanberg I., Ł. Łuczaj, M. Pardo-de-Santayana, A. Pieroni, 'History and current trends of ethnobiological research in Europe,' in Ethnobiology, eds. E.N. Anderson, K. Adams, D. Pearsall, E. Hunn, N.J. Turner (Hoboken NJ: Wiley- Blackwell, 2011), p. 192.

11. S. Lagercrantz, 'Inflated skins and their distribution,' Ethnos 9 (1944), 49-66.

12. B. Mossberg and L. Stenberg, Nordens flora (Stockholm: Bonnier Fakta, 2018), p. 775, 875.

13. K. Seidel, Die Flechtbinse Scirpus lacustris L. Ökologie, Morphologie und Entwicklung, ihre Stellung bei den Völkern und ihre wirtschaftliche Bedeutung (Stuttgart: Schweizerbart'sche Verlagsbuchhandlung, 1955); E. Kiviat and E. Hamilton, 'Phragmites use by Native North Americans,' Aquatic botany 69 (2001), 341-57; J. F. Köbbing, N. Thevs and S. Zerbe, 'The 
utilisation of reed (Phragmites australis): A review,' Mires and Peat 13 (2013), 1-14; I. Svanberg, Folklig botanik (Stockholm: Dialogos, 2011), pp. 245, 247-8.

14. Sources and their use for historical ethnobiological studies are discussed in I. Svanberg, 'Fabulat, plagiat och spökuppgifter: att använda berättande källor inom etnobiologi,' in Nycklar till kunskap: om människans bruk av naturen, eds. H. Tunón and A. Dahlström (Stockholm: Kungl. Skogs- och Lantbruksakademin, 2010), pp. 121-36; See also I. Svanberg and Å. Berggren, 'Bumblebee honey in the Nordic countries,' Ethnobiology Letters 18, No. 2 (2018), pp. 312-318.

15. E. Digby, De Arte Natandi libri duo, quorum prior regulas ipsius artis, posterior vero praxin demonstrationemque continue (Londini: Thomas Dawson, 1587).

16. Lagercrantz, p. 49.

17. J. Hornell, Water transport: Origins \& Early Evolution. (Cambridge: University Press, 1946), pp. 6-17.

18. The Nordic Museum Archives, Stockholm, Sweden: document EU 2544, EU 2596, EU 3087, EU 3235, EU 5502, EU 10130. Ethnologist Per Arvid Säve mentions the use of 'pee bladders' (pissblåsor) on the Swedish island of Gotland. P. A. Säve, Svenska lekar. 1, Gotländska lekar (Uppsala: Almqvist \& Wiksell, 1948), p. 74.

19. Olaus Magnus, Historia de gentibus septentrionalibus (Roma: Ioannem Mariam de Viottis Parmensem, 1555), p. 354.

20. J. Granlund, Kommentarer. Olaus Magnus Historia om de nordiska folken (Stockholm: Almqvist \& Wiksell, 1951), p. 243.

21. E. Brännström, Samiskt liv i äldre tid: uppteckningar från Arvidsjaur och Arjeplog (Uppsala: Kungl. Gustav Adolfs Akademien, 2017), p. 187.

22. Olaus Magnus, p. 354.

23. Granlund, p. 243.

24. C. Linnaeus, Flora lapponica (Amstelædami: Salomonem Schouten, 1737), p. 15.

25. D. Waldetoft, 'När Rya-Rya badade,' Fataburen 2004, 81-2.

26. Statens folkbadsutredning, Friluftsbad, simhallar, bastur. Simundervisning och simlärarutbildning: betänkande (Stockholm: Nord. bokh., 1954), pp. 60-1.

27. H. Sandblad, 'Läkaren Arvid Faxe, en pionjär för svensk simsport,' Idrott, historia och samhälle 1983, 65-76.

28. A. Faxe, 'Swar på Kongl. Patriotiska Sällskapets Pris-fråga: Hvilken är den bästa, lättaste och på egen erfarenhet grundade Methode til Simnings-konstens lärande för rikets ungdom?'Hushållnings Journal (October 1788), 65.

29. A. Nordenskiöld, 'Swar på Kongl. Patriotiska Sällskapets Pris-fråga: Hvilken är den bästa, lättaste och på egen erfarenhet grundade Methode til Simnings-konstens lärande för rikets ungdom?' Hushållnings Journal (Augustus 1788), 555.

30. G. Schumacher, 'Swar på Kongl. Patriotiska Sällskapets Pris-fråga: Hvilken är den bästa, lättaste och på egen erfarenhet grundade Methode til Simnings-konstens lärande för rikets ungdom?' Hushållnings Journal (December 1788), 162.

31. Faxe, p. 72; Sandblad.

32. J. Ljunggren, Kroppens bildning: Linggymnastikens manlighetsprojekt (Stockholm/Stehag: Symposion, 1999), p. 253-4.

33. Statens folkbadsutredning, pp. 60-1.

34. E. Bergvall, 'Simkunnighet,' Nordisk Familjebok, 25 (Stockholm: Nordisk familjeboks förl., 1917), pp. 568-71.

35. The Nordic Museum Archive, Stockholm, Sweden; Folk Life records: EU 7579 (Stenestad, Skåne); EU 27701 (Alseda, Småland); EU 5501 (Gryteryd, Småland); . From Alseda parish in Småland, Gottfried Wagnér recorded that the locals gathered reeds in the creek and made swim belts of it (NM: EU 27701). Another record from Gryteryd parish, Småland, mentions the use of reed bundles for the same purpose (NM: EU 5501).

36. S. Lampa, 'Folklekar från Västergötland,' Svenska Landsmål och Svenskt Folkliv 102 (1908), 43. 
37. The Nordic Museum Archive, Stockholm, Sweden; Folk Life records: EU 3235 (V. Tunhem, Västergötland), EU 4092 (Alingsås, Västergötland), EU 8467 (Husby, Östergötland), EU 2544 (Västertälje, Östergötland), EU 5502 (Kimstad, Östergötland), EU 4917 (Fläckebo, Västmanland), EU 7393 (Tuna, Dalecarlia).

38. The Nordic Museum Archive, Stockholm, Sweden: Folk Life records: EU 19008 Köla parish, Värmland, EU 2596 Graninge parish, Ångermanland.

39. A. Lundkvist, Vandrarens träd (Stockholm: Albert Bonniers, 1941), pp. 59-60. Our translation. Original quotation: 'När man gick dit efteråt låg där halvt upplösta simdynor av vass och saker som de flätat av vass, kanske med instuckna näckrosor i; man tyckte sig känna en kvardröjande lukt (av hud, hår och tvål) och spåra avtryck av deras kroppar i gräset.'

40. The Nordic Museum, Stockholm, Sweden, 'Simdynor av säv' (Film No 121 (Norra Rörum, Skåne), ht tps: / / w w w . you tube.com/watch? v=1 z H j m r y Ww 8 \& l is t = PLBC36AE3463020124\&index=39\&t=0s [accessed 25 March 2019].

41. Unknown author, '12-årig pojke drunknade i Bureälven', Svenska Dagbladet, 16 July 1945.

42. J. Schalk, 'Skrattet gav Ulla ett långt liv,' Mitt i Tyresö, 24 March 2015, p. 6.

43. V. J. Brøndegaard, Folk og flora: dansk etnobotanik, vol. 1 (København: Rosenkilde og Bagger, 1978), p. 165.

44. Hieronymus Bock, New Kreuterbuch von Underscheidt, Würckung und Namen der Kreuter, so in teutschen Landen wachsen (Straßburg: Wendelin Rihel, 1551), p. 262r.

45. H. Marzell, Wörterbuch der deutschen Pflanzennamen, vol. 4 (Stuttgart: Hirzel Verlag, 1979), p. 169.

46. K. Applelt, 'Arundo donax. Ein kulturgeschichtliches Mosaik,' Wiener Zeitschrift für die Kunde des Morgenlandes 48 (1941), p.191; Seidel, p. 84.

47. W. Ostendorp and M. Dienst, 'Geschichte der Seeuferröhrichte in der Grenzzone des Bodensee-Untersees,' Mitteilungen der Thurgauischen Naturforschenden Gesellschaft 66 (2012), pp. 155-97.

48. A. Kalamees, Eesti rahvamänge (Tallinn: Eesti Riiklik Kirjastus, 1960), p. 161.

49. M. Anderson, 'Sami children and traditional knowledge,' in Ecological Knowledge in the North: Studies in Ethnobiology, eds. I. Svanberg and H. Tunón (Uppsala: CBM, 2000), pp. $55-65$.

\section{Disclosure statement}

No potential conflict of interest was reported by the authors.

\section{Notes on contributors}

Isak Lidström is a sports historian and a $\mathrm{PhD}$-student at the department of Sport Science, Malmö University. His research interests include Sámi sport history, sport among ethnic minorities and traditional ball games.

Ingvar Svanberg is an ethnobiologist and senior research fellow at the Institute for Russian and Eurasian Studies, Uppsala University. His research interests include cultural zoology, ethnobotany, food culture and local knowledge about the biota. 